Binghamton University

The Open Repository @ Binghamton (The ORB)

\title{
8-2015
}

\section{Powering sustainability: municipal utilities and local government policymaking}

George C. Homsy

Binghamton University--SUNY, ghomsy@binghamton.edu

Follow this and additional works at: https://orb.binghamton.edu/public_admin_fac

Part of the Public Administration Commons

\section{Recommended Citation}

Homsy, George C., "Powering sustainability: municipal utilities and local government policymaking" (2015). Public Administration Faculty Scholarship. 19.

https://orb.binghamton.edu/public_admin_fac/19

This Article is brought to you for free and open access by the Public Administration at The Open Repository @ Binghamton (The ORB). It has been accepted for inclusion in Public Administration Faculty Scholarship by an authorized administrator of The Open Repository @ Binghamton (The ORB). For more information, please contact ORB@binghamton.edu. 


\title{
Powering sustainability: municipal utilities and local government policymaking
}

\author{
Abstract \\ Sustainability policymaking presents numerous challenges to local governments. Municipal \\ leaders, especially in smaller cities and towns, report that they lack the fiscal capacity and/or \\ technical expertise to adopt many environmental protection policies. This paper investigates \\ whether the more than 2,000 municipally-owned utilities have the potential to mitigate those \\ problems. Data from two surveys of local governments in the United States $(n=861)$, modeled in \\ a pair of negative binomial regressions, finds a positive correlation between those cities with \\ municipal power companies and those with an increased number of community-wide sustainable \\ energy policies. Follow-up interviews with officials reveal the potential mechanisms driving \\ sustainability by local governments that own power companies. These mechanisms are the \\ increased capacity that publicly-owned utilities provide by virtue of income generated and access \\ to energy-specific grants as well as the local nature of their operations, which allows a better fit \\ of sustainable energy measures to local circumstances.
}

\section{Introduction}

Local governments in the United States have been touted as an appropriate level for sustainability policymaking in areas such as climate change mitigation and energy conservation (e.g. Ostrom, 2010; Rayner, 2010). Municipal efforts are increasingly recognized and supported by other governmental levels (Barboza, 2014; Council on Environnmental Quality, 2013) as well as national and international non-governmental organizations (Betsill and Bulkeley, 2004; Krause, 2012). Municipalities tackle such issues by making their own operations more energy efficient as well as by adopting policies that entice or compel action by citizens and businesses through regulations, incentives, or other programs (Betsill and Bulkeley, 2006). Across a 
community, local governments directly control or can impact building energy use (e.g. building codes, retrofit programs, incentives for renewable power), urban passenger transport (e.g. planning denser neighborhoods, public transit improvements, management of transport flow), urban freight transport, and urban waste management (Erickson and Tempest, 2014).

Local government sustainability literature describes the characteristics of municipalities that act on various issues of sustainability. Factors positively correlated to local sustainability policymaking include the presence of a city manager, local capacity, state government rules or incentives, political culture, and citizen activism (Berry and Portney, 2013; Homsy and Warner, 2015; Kwon et al., 2014; Millard-Ball, 2012; Saha, 2009; Svara, 2011). However, much of this research as well as the popular press and policies focus on big cities. (See, for example, Council on Environnmental Quality, 2013.) Research shows that smaller municipalities and rural communities are slower to adopt sustainability policies due to fiscal and technical capacity constraints (Conroy and Iqbal, 2009; Homsy and Warner, 2012; Lubell et al., 2009; Tang, 2009).

There are more than 2,000 municipally-owned utilities in the United States and their role as a local government actor is not well examined, especially in terms of sustainable energy policymaking. Municipal utilities are power companies owned and operated by local governments, often as a municipal department or related governmental authority. The governing body of the utility may be the governing body of the municipality (e.g. city council, town board, etc.) or a separate board that is elected by residents or appointed by elected officials (American Public Power Association, 2013). Municipal utility board members tend to be politically influential members of the community (Wilson et al., 2008). The local nature of publicly owned utilities makes them more responsive to community demands; in some cases citizens may vote on operational decisions to be made by the utility (Smeloff and Asmus, 1997). 
Supporters of municipal utilities tout their economic development benefits, which are related to lower energy costs and the ability to keep utility income local (American Public Power Association, 2014). Neither the scholarly literature nor professional publications examine in any depth municipal utilities' role in sustainability. (Exceptions include Flanigan and Hadley, 1994, Krause, 2011, and Wilson et al., 2008.) This is an important gap because most of the utilities are located in smaller communities; those places that the research tells us struggle with environmental protection efforts. Research into the role of municipal utilities can inform policymakers seeking to broaden local government climate change and energy conservation efforts beyond the world's biggest cities.

This paper seeks to fill this gap in the literature with a mixed methods approach to the following two research questions. First, I examine whether the presence of a municipal utility impacts energy sustainability policymaking by local governments - both in terms of their own operations and across their communities. Second, I seek to uncover the causal pathways by which these utilities may play a role in energy policymaking by local governments. My research finds that the presence of municipal utilities supports local sustainability action by virtue of the added fiscal and technical capacity of the utilities and to the increased effectiveness of locally crafted programs.

In the following section, I provide a conceptual framework for local government policymaking and the challenges faced in terms of adopting climate change and sustainable energy policies, especially in smaller communities. I then describe municipal utilities and their role in local government. In section four I explain the mixed methods approach for this research. I then separately present my statistical and case example findings, followed by my conclusion, which includes implications for local government policymaking. 


\section{Smaller places: struggling for sustainability}

The overall adoption rate of sustainability policies among municipalities is low (Svara, 2011) with smaller communities (fewer than 25,000 residents) enacting half the number of policies of those municipalities between 100,000 and 1,000,000 in population (Homsy and Warner, 2012). This is troubling because in 2010, the U.S. Census found that half of Americans live in communities with fewer than 25,000 residents. Although many of these municipalities are in metropolitan regions, each local government typically has significant control over the public and private sector factors that influence sustainability within their borders. Only one-fourth of Americans live in the 274 U.S. cities with more than 100,000 residents.

Local governments usually act on environmental matters when they are forced to or incentivized by a higher level of government (Jepson, 2004; Lubell et al., 2009). This top-down, command and control regulation allowed the U.S. to become an early leader in eliminating the worst water and air pollution. However, this approach often leaves little room for local discretion, may fail to find local support, stifles local innovation, and has proven less effective with more complex environmental problems (Burby and May, 1998; Fiorino, 2006, 2010). On their own individual municipalities have little economic incentive to adopt environmental policies that protect the regional or global commons due to capacity constraints (fiscal, managerial, and civic), the ability to free ride on the activities of a nearby major city, and the inability to coordinate across jurisdictions (Homsy and Warner, 2015). Small and rural communities in particular are slow to implement local climate change action due to capacity constraints, political culture, and the lack of information about effective policies (Carter and Culp, 2010).

Local governments tend to act on a regional or global commons issue when such action is tied to an issue already on the local agenda (Betsill, 2001). These internal drivers include, for 
example, fiscal cost savings through energy conservation at municipal facilities (Kousky and Schneider, 2003) and economic development (Jochem and Madlener, 2003). Population growth can cause residents to push their elected officials to increase sustainability action (Hanna, 2005).

Municipalities are an appropriate level for tackling commons issues because local governments can respond to the preferences of their residents. Cities and towns can also better fit solutions to local situations and politically test innovative policies. Acceptance of policies, which may lead to better implementation and enforcement, may be higher if the new rules are locally crafted (Lutsey and Sperling, 2008). Municipal successes might also inspire higher levels of government to adopt similar policies (Fisher, 2013; Ostrom, 2010a). At the same time, the extent to which municipalities can act on any issue including sustainability is limited by powers granted to them by the 50 different state governments (Frug and Barron, 2008).

Lack of capacity can also inhibit policy implementation. Local governments need technical and financial resources to adopt and implement most policies (Thompson, 1965) with increasingly complex policy requirements demanding higher levels of resources (Honadle, 2001). Technical capacity can be found in the professionalization of staff. The presence of municipal managers correlates to more innovative local policies in general (Nelson and Svara, 2012) and more sustainability policies in particular (Svara, 2011). However, Bae and Feiock (2013) found that the presence of a city manager only correlates with increased sustainability in municipal operations, and that a city manager's presence reduces the predicted number of community-wide policies. Local governments can also utilize the expertise of their citizens (Taylor, 2000; Wallis and Dollery, 2002) and civic engagement can lead to the greater adoption of sustainability policies (Portney and Berry, 2010).

Financial capacity is also important to policymaking. Sustainability efforts increase with better fiscal health of the local government (Lubell et al., 2009; Sharp et al., 2011; Zahran et al., 
2008). In other areas, greater fiscal resources lead to more economic development policymaking (Betz et al., 2012), and the lack of fiscal capacity reduces the ability of local governments to adopt hazard mitigation plans (May et al., 1996). In Sacramento, California, the 1930s effort to municipalize electricity was driven in part by the need to expand fiscal capacity as the new revenues were planned to fund drinking water purification projects (Smeloff and Asmus, 1997).

\section{Municipal utilities in the United States}

The municipal utility is one of five types of electricity providers in the United States. As illustrated in Table 1, there are just over two thousand municipal utilities, which serve 14.4 percent of customers. During the late $19^{\text {th }}$ and early $20^{\text {th }}$ centuries, each local government made its own decision about whether to form a government-owned utility or to allow private ownership. In some cities policy reformers held power and municipally-owned utilities were formed while in others private providers won out (Rudolph and Ridley, 1986; Schap, 1986). Municipal utilities were also established to forward the interests of local business leaders as in Los Angeles, where the municipal electric service and the municipal water system were designed to foster city growth.

In many places, public power was a reaction to the inequitable pricing system by private utilities in which smaller customers subsidized industrial electricity consumption. Municipal utilities were also touted as a profitable business for local government, which could subsidize other city ventures, such as the municipal water system (MacKillop, 2005). In some smaller cities, municipal utilities took hold because these places were unable to attract private utilities to invest in local systems, and, unlike in bigger cities, these smaller places also did not have entrenched investor-owned operations fighting to keep control of the power industry (Hausman and Neufeld, 1990; Schap, 1986). 
Table 1 - The US Electricity Industry (2012)

\begin{tabular}{|l|c|c|c|}
\hline \multicolumn{1}{|c|}{ Power provider } & Number of utilities & Share of total utilities & Share of total customers \\
\hline Municipal utilities & 2,009 & $61.0 \%$ & $14.4 \%$ \\
Investor owned utilities & 192 & $5.8 \%$ & $68.5 \%$ \\
Cooperatives & 871 & $26.5 \%$ & $12.8 \%$ \\
Federal Power Agencies & 9 & $0.3 \%$ & $0.0 \%$ \\
Power marketers $^{1}$ & 211 & $6.4 \%$ & $4.3 \%$ \\
\hline
\end{tabular}

(Data source: American Public Power Association, 2014)

Although some very large cities have municipal utilities (including Los Angeles, California, Seattle, Washington, and Austin, Texas), the bulk of government-owned power companies are in smaller communities and therefore have smaller customer bases as shown in Figure 1. In the early years both investor-owned and municipally-owned utilities urged consumers to increase their use of electricity, especially in rural areas, in an effort to boost the power market (Harrison, 2013). Among other strategies, the utilities required home wiring include several outlets in addition to lights; peddled new electric appliances; and imposed minimum monthly charges.

${ }^{1}$ Power marketers, based largely in Texas, do not own generation or distribution, but are resellers of electricity. 
Figure 1 - Distribution of municipal utilities by number of customers

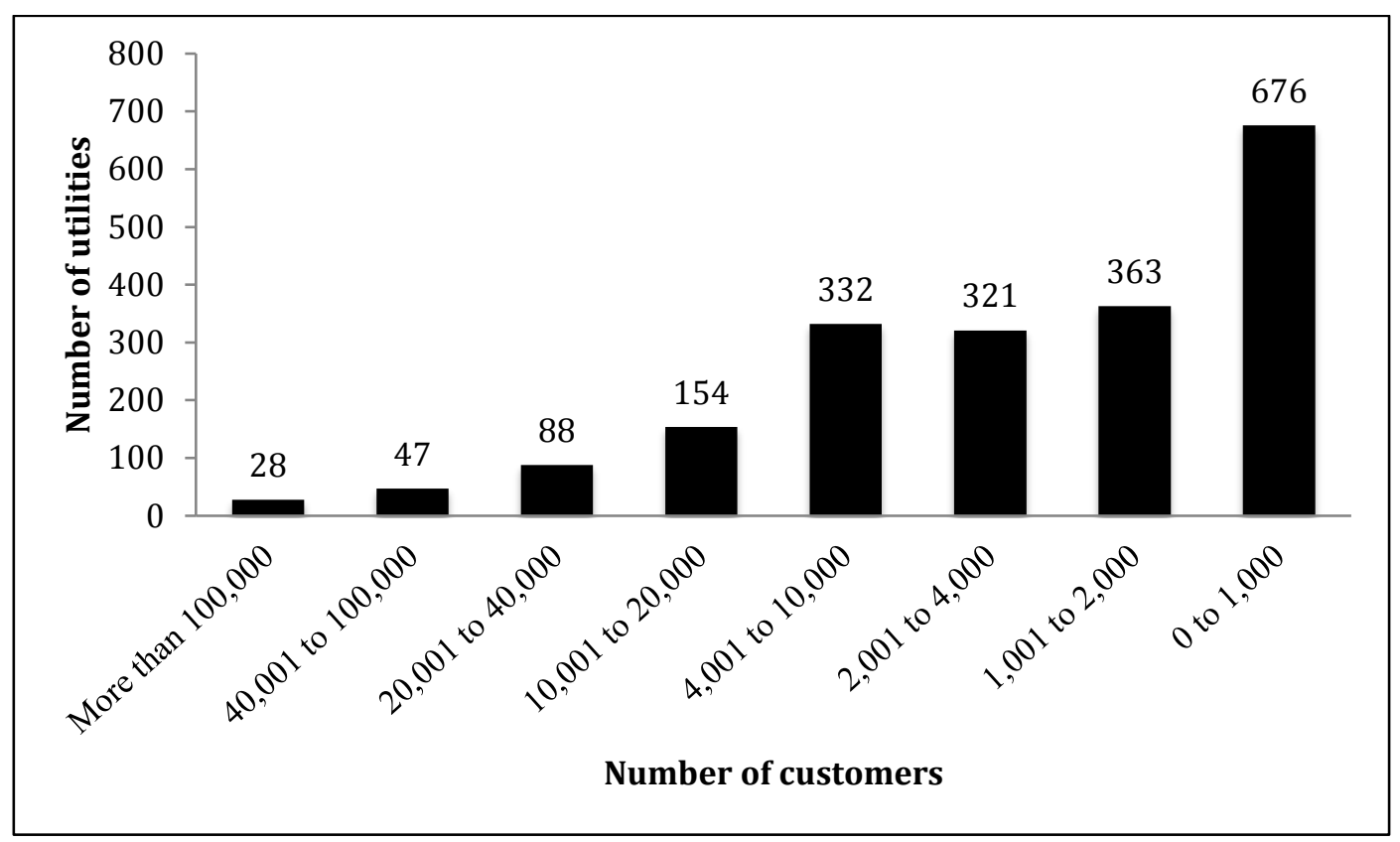

(Data source: American Public Power Association, 2014)

The growth of municipal power stopped in the early 1920s. Private utilities had waged extensive propaganda battles against municipal power companies (often warning about the socialist nature of public enterprises) and pushed through state legislation that made the establishment and expansion of public power utilities difficult (Rudolph and Ridley, 1986). Personal relationships among the private power company elites and equipment manufacturers limited the ability of the many municipal utilities to expand their service areas or increase production capacity (Granovetter and McGuire, 1998). Officials at investor-owned utilities also became resigned to the conclusion that the electricity provision was a natural monopoly and they then submitted to state-level regulation, which blunted much of the public wariness of private power companies (Rudolph and Ridley, 1986). Local municipalization of electric systems gained a little during the New Deal, when federal power projects favored municipal utilities, and customers expressed concern over widespread consolidation of the private market and 
dissatisfaction with state regulation (Hausman and Neufeld, 2011; Hyman, 1997). Again in the 1980s, dramatically rising electricity rates due to the construction of nuclear power plants pushed some local governments to municipalize their systems (Rudolph and Ridley, 1986). Citizen calls for a more sustainable energy system was a major driver of Boulder, Colorado's municipalization effort (Driskell, 2012). In the three decades leading up to 2013, 59 governmentowned utilities were created due to poor service, increased number of power outages, and higher power prices of the private utilities they replaced (American Public Power Association, 2013).

In 2012, municipal utilities nationally provided about 12 percent lower electric rates to residential customers (and five percent lower to all customers) than investor-owned utilities. This lower price is a major component of the economic development argument for municipalization of electricity. Other economic development benefits include the local circulation of money from utility purchases and, with workers drawn from the community, better service, especially following power outages. Public power advocates also tout improved governmental efficiency through sharing with other municipal departments, local control over utility programs, facility aesthetics, and the ability to focus on community goals that meet local needs (American Public Power Association, 2014).

There exists little literature about the potential for environmental protection benefits in communities with municipally-owned power companies. Municipal utilities have more renewable energy in their portfolios than private utilities, due largely to public hydroelectric facilities. Several large municipal utilities have become leaders in promoting energy efficiency and renewable energy (Heiman and Solomon, 2004). Flanigan and Hadley (1994) identified common factors in promoting energy conservation among municipal utilities, but did not compare efforts between government-owned and investor-owned utilities. Sippel and Jenssen (2009) did find an advantage in the access that local officials have to energy usage data in 
communities with municipal utilities. Investor-owned utilities tend to be less forthcoming with this important benchmarking information as they may consider the information proprietary. Wilson et al. (2008) found that municipally-owned power companies enhanced customer relations and, with that, the utilities were able to build more partnerships in the community, which facilitated the increased marketing of energy conservation programs. However, Krause (2011) found that the presence of a municipal utility, particularly a smaller one, reduces a local government's likelihood to have signed the Mayor's Climate Protection Agreement, which is a non-binding pledge to reduce greenhouse gas emissions. Municipal utilities in California also successfully lobbied to avoid state renewable energy mandates (Heiman and Solomon, 2004).

\section{Data and Methodology}

This paper offers a mixed methods approach to understanding whether or not the presence of a municipal utility influences local government energy sustainability efforts, and it explores the potential causal mechanisms involved in those policy decisions. This mix of methods allows a deeper investigation into the causes of the observed phenomena by using qualitative research to build a case that explains the initial statistical results (Axinn and Pearce, 2006; Creswell and Clark, 2011).

I first use a statistical analysis to examine whether two measures of energy sustainability policymaking by local government are impacted by the presence of a utility. The two dependent variables are similar in construction (though based on different data) as those constructed by Bae and Feiock (2013). One of these involves sustainable power policies in local government operations. The other measures policies seeking to influence the greater community. These represent two very different decisions made by local governments seeking to conserve energy or reduce greenhouse gas emissions; the first has an important co-benefit to the municipality itself 
in terms of saving energy costs while the second does not. In the second part of the analysis, I use a series of exploratory interviews to try to understand the role of municipal utilities as influential institutions acting on local government.

\section{Quantitative methodology}

The data for this analysis comes from two surveys conducted by the International City County Management Association (ICMA). In 2010, ICMA surveyed all city-type governments and counties with populations over 2,500. The survey asked about the adoption of sustainability policies in 12 issue areas. From this policy list I developed the two dependent variables for local government: the number of government energy sustainability policies and the number of community-wide energy sustainability polices. The exact wording from the surveys of policies included in each dependent variable can be found in Table 2.

The second data source is the 2012 ICMA survey of local government service delivery choices, which went to all city-type governments over 2,500 and all counties with a functioning government. The survey asks about the availability and delivery method for 76 public services and provided my independent variable of interest, which is whether local government provided municipal electric or gas utility service. I use two negative binomial models to examine the research question because the dependent variables are not normally distributed, include many zeroes, and are over dispersed. I also use robust standard errors to account for the clustering of municipalities within the U.S. states. 
Table 2 - Policies included in the count of each dependent variable

Number of Government energy sustainability policies (potential count range 0 to 21)

Respondents were asked if their municipality adopted or undertook the following.

- Established baseline greenhouse gas emissions of local government

- Established greenhouse gas emissions targets for local government operations

- Established a fuel efficiency target for the government fleet of vehicles

- Increased the purchase of fuel efficient vehicles

- Purchased hybrid electric vehicles

- Purchased vehicles that operate on compressed natural gas (CNG)

- Installed charging stations for electric vehicles

- Conducted energy audits of government buildings

- Installed energy management systems to control heating and cooling in buildings

- Established policy to only purchase Energy Star equipment when available

- Upgraded or retrofitted facilities to higher energy efficiency office lighting

- Upgraded or retrofitted traffic signals to improve efficiency

- Upgraded or retrofitted streetlights and/or and other exterior lighting to improve efficiency

- Upgraded or retrofitted facilities to higher energy efficiency heating and air conditioning system

- Upgraded or retrofitted facilities to higher energy efficiency pumps in the water or sewer systems

- Utilize dark sky compliant outdoor light fixtures

- Installed solar panels on a government facility

- Installed a geo-thermal system

- Generated electricity through municipal operations such as refuse disposal, wastewater treatment, or landfill

- Require all new government construction projects to be LEED or Energy Star certified

- Require all retrofit government projects to be LEED or Energy Star certified

Number of Community-wide energy sustainability policies (potential count range 0 to 20)

Respondents were asked if their municipality adopted or undertook the following.

- Established baseline greenhouse gas emissions for the community

- Established greenhouse gas reduction targets for businesses

- Established greenhouse gas reduction targets for multi-family residences

- Established greenhouse gas reduction targets for single-family residences

- Energy Audit-Individual residences

- Weatherization- Individual residences

- Heating / air conditioning upgrades- Individual residences

- Purchase of energy efficient appliances- Individual residences

- Installation of solar equipment- Individual residences

- Energy Audit-Businesses

- Weatherization-Businesses

- Heating / air conditioning upgrades-Businesses

- Purchase of energy efficient appliances-Businesses

- Installation of solar equipment-Businesses

- Has your local government established any energy reduction programs targeted specifically to assist low-income residents?

- Has your local government established any energy reduction programs targeted specifically to assist small businesses?

- Require charging stations for electric vehicles

- Incentives other than increased density for new commercial development (including multi-family residential) that are LEED Certified or an equivalent

- Incentives other than increased density for new single-family residential be LEED certified or the equivalent

- Residential zoning codes to permit solar installations, wind power, or other renewable energy production 
The literature has identified various factors that correlate to sustainability policymaking and I use those factors as independent control variables in my analysis. Descriptive statistics and sources for all variables are found in Table 3. The external influence variable, state climate policy index, recognizes that municipalities in the United States are constituents of state-level governments (Frug and Barron, 2008) and is an additive index comprising climate change and energy sustainability policies adopted by each state $^{2}$.

The capacity variables examine the ability of a municipality to carry out policies. For financial capacity, we look to local government revenue per capita as a measure of a community's ability to raise money and fund policymaking and programming. Civic capacity is measured by the presence of a citizen commission designated to addresses sustainability issues. Another capacity variable is presence of a professional city or town manager, which has been positively correlated to more innovative policymaking (Nelson and Svara, 2012), though managers may influence different kinds of policies in different ways (Bae and Feiock, 2013). The final capacity variable is membership in ICLEI-Local Governments for Sustainability, an international nonprofit membership organization of local governments. ICLEI works with municipalities across a range of sustainability issues providing technical and political support (Betsill and Bulkeley, 2006) and membership has been correlated with small to moderate increases in energy conservation and climate change policymaking (Krause, 2012). The

\footnotetext{
2 The state climate policy index variable is an additive index based on the following actions undertaken by a state government: established a greenhouse gas emissions target; enacted an emissions cap for electricity producers; adopted a climate change action plan; formed climate change commissions and advisory groups; created a state adaption plan; dedicates a public benefit fund to promote energy efficiency or renewable energy production; requires electric utilities to deliver a certain amount of energy from renewable sources; permits some level of net metering; mandates green pricing options for retail electricity customers; adopts California vehicle emissions standards; mandates or promotes biofuels for vehicles; maintains statewide goals, targets, or policies aimed at reducing vehicle miles traveled; adopted a low carbon fuel standard for transportation fuels; mandates state purchase of electric cars or incentivizes private sector purchase and operation; recommends or requires building standards based upon the LEED green building rating system of the U.S. Green Building Council; enables "property assessed clean energy financing" for clean energy installations or retrofits; and sets a higher minimum standard for appliance efficiency than federal law (Data source: Center for Climate and Energy Solutions, 2011).
} 
socioeconomic controls are the log of population, population density, population growth, educational attainment, and per capita income, owner occupancy, housing vacancy and metropolitan status of the community.

Only municipal governments under 1,000,000 in population that answered both surveys were included in the analysis ( $\mathrm{n}=861$ in 48 states). The representativeness of the final sample is measured against the universe for the 2012 service delivery survey, which encompassed the universe for the 2010 sustainability survey, and contained 7,374 municipal governments (counties are excluded from this analysis). There are two limitations to note about the quantitative analysis. First, the final response rate is 11.7 percent. Second, not surprisingly given the use of two surveys, Chi-Square Goodness of Fit tests indicates that the final sample significantly differs from the universe in terms of local government size and geographical distribution. Municipalities ranging in size from 25,000 to 249,999 are somewhat over represented as are the smallest local governments, which range from 2,500 to 4,999 in population. In terms of geographic regions, the north-central U.S. and the West are overrepresented. Despite this weakness, the number of observations in the analysis and the likely self-selection bias towards places that undertake sustainability action on the sustainability survey may strengthen the final results. This is because we are testing whether or not places with municipal utilities $(\mathrm{n}=244)$ undertake more policies and in this case we have a pool of places more likely to act in that manner whether or not they have municipal utilities. 
Table 3 - Descriptive Statistics

\begin{tabular}{|c|c|c|c|c|}
\hline Variables & $\begin{array}{l}\text { Mean (or proportion } \\
\text { yes for } 1 / 0 \text { variables) }\end{array}$ & $\begin{array}{l}\text { Standard } \\
\text { deviation }\end{array}$ & Min & Max \\
\hline \multicolumn{5}{|l|}{ Dependent variables } \\
\hline Energy sust. in govt. operations ${ }^{a}$ & 5.1 & 4.0 & 0 & 19.0 \\
\hline Energy sust. across community ${ }^{a}$ & 2.7 & 2.0 & 0 & 14.0 \\
\hline \multicolumn{5}{|l|}{ Independent variables } \\
\hline \multicolumn{5}{|l|}{ Treatment variable } \\
\hline Presence of a municipal utility ${ }^{\mathrm{b}}$ & 0.28 & 0.5 & 0 & 1 \\
\hline \multicolumn{5}{|l|}{ External influence variables } \\
\hline State climate policy index ${ }^{\mathrm{d}}$ & 10.2 & 4.3 & 0 & 17.0 \\
\hline \multicolumn{5}{|l|}{ Capacity variables } \\
\hline Local tax revenue per capita & 973.9 & 862.0 & 0 & 11,421 \\
\hline Citizen commission for sust. ${ }^{a}$ & 0.25 & 0.44 & 0 & 1 \\
\hline Presence of city/town manager & 0.66 & 0.48 & 0 & 1 \\
\hline Member of ICLEI ${ }^{\mathrm{c}}$ & 0.10 & 0.3 & 0 & 1 \\
\hline \multicolumn{5}{|l|}{ Sociodemographic controls } \\
\hline Population size ${ }^{\mathrm{g}}$ & 28,278 & 54,536 & 2,328 & 649,121 \\
\hline Population density ${ }^{\mathrm{f}}$ & $2,079.2$ & $1,755.1$ & 3.1 & $14,221.7$ \\
\hline Population change $2000-2010^{\mathrm{g}}$ & 16.1 & 36.8 & -18.9 & 510.8 \\
\hline Pop. with bach. deg or more ${ }^{f}$ & 18.6 & 8.9 & 1.79 & 46.4 \\
\hline Per capita income ${ }^{f}$ & 28,624 & 13,443 & 5,639 & 115,334 \\
\hline Owner occupancy rate ${ }^{g}$ & 66.4 & 13.2 & 20.3 & 97.5 \\
\hline Housing vacancy rate ${ }^{g}$ & 9.8 & 8.0 & 2.0 & 69.5 \\
\hline Metropolitan status ${ }^{\mathrm{a}}$ & Number & $\underline{\text { Percent }}$ & & \\
\hline Urban (reference variable) & 110 & 12.8 & & \\
\hline Suburban & 546 & 63.4 & & \\
\hline Rural & 205 & 23.8 & & \\
\hline
\end{tabular}

Data sources: a $\left(\right.$ ICMA, 2010) ${ }^{b}\left(\right.$ ICMA, 2012) ${ }^{c}\left(\right.$ ICLEI, 2011) ${ }^{d}($ Center for Climate and Energy Solutions, 2011) ${ }^{\mathrm{e}}$ (U.S. Census Bureau) ${ }^{\mathrm{f}}$ (U.S. Census Bureau) ${ }^{\mathrm{g}}$ (U.S. Census Bureau)

\section{Qualitative methodology}

Given the exploratory nature of my qualitative research question, the sample for case examples was purposive rather than random and not meant to be representative of any universe of municipalities. Case example communities were chosen from a list of those places with a municipal utility and with relatively high scores on the dependent variables. Table 4 lists the case 
example communities and some descriptive statistics for each. Since I sought to learn about the promises and challenges connected to owning a municipal utility, I did not choose to examine any negative cases (e.g. places without a municipal utility or those with a utility that performed poorly in the dependent variables). In each community I spoke with one or two of the following officials: chief elected or administrative official, one of their deputies, a sustainability officer, or the person in charge of their energy or utility programs. A total of 13 people were interviewed in the eleven communities from nine states. Interviews were semi-structured, conducted over the telephone, and the officials interviewed were not promised confidentiality.

The major limitation of the qualitative analysis is the low number of case communities $(n=11)$. This naturally limits the generalizability of these findings. However, rather than seeking generalizable findings, I am hoping to explore the bounds of potential causal factors. Future research will more thoroughly examine the generalizability of various factors.

\begin{tabular}{|l|r|r|r|c|}
\hline Table 4 - Descriptive statistics of communities \\
\hline \multicolumn{1}{|c|}{ Name } & $\begin{array}{c}\text { Population } \\
(2010)\end{array}$ & $\begin{array}{c}\text { Pop. Growth } \\
2000-2010\end{array}$ & $\begin{array}{c}\text { Per capita } \\
\text { income (2006- } \\
2010 \text { ACS) }\end{array}$ & Metro status \\
\hline City of Gunnison, CO & 5,854 & $8.2 \%$ & $\$ 17,394$ & Rural \\
City of West Liberty, IA & 3,736 & $12.1 \%$ & 16,502 & Rural \\
City of Naperville, IL & 144,864 & $10.5 \%$ & 45,488 & Central city \\
Town of Berlin, MD & 4,485 & $28.5 \%$ & 24,151 & Suburban \\
City of Sleepy Eye, MN & 3,599 & $2.4 \%$ & 21,883 & Rural \\
Town of Cornelius, NC & 24,866 & $107.8 \%$ & 50,169 & Suburban \\
Village of Tupper Lake, NY & 3,667 & $-6.8 \%$ & 21,259 & Rural \\
City of Oberlin, OH & 8,286 & $1.1 \%$ & 18,872 & Suburban \\
City of Hurricane, UT & 13,748 & $66.6 \%$ & 21,650 & Suburban \\
City of Lake Mills, WI & 5,708 & $17.9 \%$ & 28,076 & Rural \\
City of River Falls, WI & 15,000 & $19.4 \%$ & 20,152 & Suburban \\
\hline
\end{tabular}




\section{Municipal utilities and community sustainability}

The statistical results of the two negative binomial regression models are found in Table 5 and are presented as incidence rate ratios, which predict the rate of change in the count of the dependent variable (i.e. the predicted percentage change in the number of policies). To ensure that extensive sustainability policymaking in the largest cities did not swamp the models, each model was rerun for municipalities under 100,000 in population only $(n=813)$ and again for those under 50,000 in population $(n=740)$. In all cases, the models were stable with the role of the municipal utility remaining the same.

The independent variable of interest, the presence of a municipal utility, was only significant in the second model, which predicts that the count of community wide sustainable energy policies would increase by almost 29 percent with the presence of a municipal utility. Two theoretical reasons and one methodological one might explain the difference in the role of the municipal utility in the two models. First, local government operations, which are measured in the first model, are relatively easier to change than community-wide ones. Also, these policies often have direct fiscal benefits to the local government and this incentive is important to communities whether or not they own a municipal utility (Kousky and Schneider, 2003). Finally, the survey might be biased towards local governments that act on sustainability and therefore hide the role of the municipal utility in the first model.

Interestingly, in the first model, in which presence of municipal utilities is not significant, all four of the capacity variables are significantly correlated to the count of local government energy policies. Local governments need capacity to adopt policies even if these policies would provide an important co-benefit, such as reducing municipal costs. The opposite is nearly true in the model of community energy policies where only the presence of a citizen commission for sustainability is a significant capacity variable. This result indicates the potentially important role 
of municipal utilities in providing fiscal and technical capacity to a local government. I explore this more in the next section.

The state influence variable is significant in both models and has a similar incident rate ratio, which is expected given the strong state role in municipal affairs. As is common in analyses of local governments, the population size is significantly correlated to sustainability policymaking in all three models. Change in population is also positively correlated to the count of community-wide energy policies, which may be the result of citizens putting pressure on their local governments to control growth (Hanna, 2005). Rural communities have a higher predicted rate of sustainability policymaking in this area of energy, a finding that may result from their distance to urban cores and their inability to free ride on environmental policies (Homsy and Warner, 2015).

The results seem to run counter to a previous study (Krause, 2011) that finds municipal utilities decrease the likelihood that local governments will pledge to act on climate change issues. One possible explanation for this may lie in the nature of the different dependent variables used in the two studies. Krause uses the signing of a non-binding political pledge - the Mayor's Climate Protection Agreement (MCPA) while the dependent variables used in the current paper are indices of policy actions. Another reason for the differing results may be that most of the policy action by MCPA signatories involve changes to government operations and services (U.S. Conference of Mayors, 2008). This finding, the actually offers support for my study's finding of no significant role for municipal utilities in policymaking of government operations. 


\begin{tabular}{|c|c|c|}
\hline Variables & $\begin{array}{l}\text { 1. Local govt. } \\
\text { energy policies } \\
\text { (IRR) }\end{array}$ & $\begin{array}{l}\text { 2. Comm. wide } \\
\text { energy policies } \\
\text { (IRR) }\end{array}$ \\
\hline \multicolumn{3}{|l|}{ Variable of interest } \\
\hline Presence of a municipal utility & 1.017 & $* * 1.295$ \\
\hline \multicolumn{3}{|l|}{ External influence variable } \\
\hline State climate policy index & $* 1.023$ & $* * 1.024$ \\
\hline \multicolumn{3}{|l|}{ Capacity variables } \\
\hline Local tax revenue per capita & $* * 1.000$ & 1.000 \\
\hline Citizen commission for sust. & $* * 1.203$ & $* * 1.167$ \\
\hline Presence of city/town manager & $* 1.183$ & 1.058 \\
\hline Member of ICLEI & $* * 1.209$ & 1.141 \\
\hline \multicolumn{3}{|l|}{ Sociodemographic controls } \\
\hline Population (log) & $* * 1.380$ & $* * 1.090$ \\
\hline Population density & 1.000 & 1.000 \\
\hline Population change 2000 - 2010 & 1.000 & $* * 1.001$ \\
\hline Pop. with bach. deg or more & 1.009 & 1.007 \\
\hline Per capita income & 1.000 & 1.000 \\
\hline Owner occupancy rate & 1.000 & 0.998 \\
\hline Housing vacancy rate & 1.002 & 1.001 \\
\hline \multicolumn{3}{|l|}{ Metropolitan status } \\
\hline Urban (reference value) & & \\
\hline Suburban & 1.062 & 0.882 \\
\hline Rural & $* 1.246$ & 1.020 \\
\hline
\end{tabular}

$*$ significant at the 0.05 level, ** significant at the 0.01 level

\section{Municipal utilities and avenues of action on sustainability}

The statistical analysis finds a correlation between the presence of a municipal utility and local government action on energy issues across the community. The analysis also indicates that the role of municipal capacity is important. A second method of inquiry, interviews with local officials in communities, allows me to investigate potential avenues of causation and expand upon the results of the regression models. This section is exploratory and it relies on the qualitative analysis of relatively few case examples (rather than full case studies). Still it offers important insight into the potential power of municipal utilities to aid in local sustainability. 


\section{Fiscal and capacity}

The interviews find that the most common role for municipal utilities is the municipal power company’s ability to garner additional capacity, especially fiscal resources, for sustainability efforts. First, and most simply, the excess in revenue generated over production and distribution costs (which would be profit in investor-owned operations) is used to fund sustainable energy initiatives in six of the 11 municipalities. The most common activity was to purchase energy efficient light bulbs, which the utilities provided for free or at a reduced cost to customers. Other uses for the excess utility revenue are energy efficiency renovations in municipal buildings, the purchase of greener vehicles for municipal fleets, installation of high efficiency streetlights, solar-powered crosswalk lights, solar panels on schools, and subsidies to help local businesses and homeowners defray the cost of solar panels. In some places, both residents and industrial corporations benefited from the municipal utility offering subsidies to upgrade appliance or equipment that reduced energy consumption. "I think it would be very hard to [subsidize appliance purchases] without... this type of revenue generation," reported one local official.

Another avenue of fiscal capacity opened by the municipal utilities is access to state, federal, and other energy grant programs. For example, the municipal electric utility in one community works with a private natural gas utility on projects to reduce energy consumption that the private entity is required by state law to fund. The presence of a municipal utility also provides a means of applying for grants that require matching funds. In discussing the importance of grants for energy sustainability, one local official stated that he did not think “there would be a lot of expenditure into this type of operation if we didn't have the municipal utility" Another small city uses utility revenue to supplement the local school's science 
education by funding a teacher who works with second and fourth graders to understand energy production and conservation science. In another city, the city manager reported that presence of the municipal utility allowed them to provide more cost effective drinking water treatment; the city changed from a more costly chlorination drinking water treatment to an electricity-based process that also reduced the potential for contamination.

The presence of a utility adds to a community's technical capacity in numerous ways, according to officials. The staff of the public power company in one town performs home energy audits and uses their utility pole maintenance equipment to support other city efforts, such as putting up banners around town. Many municipal utilities also belong to statewide public power associations. A few of these organizations, in addition to advocating for their members and providing management or technical training, offer support to conservation programs. For example, the Utah Associated Municipal Power Systems administers smart energy programs for customers of member utilities to receive financial incentives to upgrade to more energy efficient appliances, such as washing machines, air conditioners, and refrigerators (UAMPS, 2014). In this way utility members, who participate do not need to create the technical infrastructure and capacity to administer such green policy programs.

Although this research is not meant to examine negative cases in which local governments do not have a municipal utility, one interview subject was able to reflect on previous employment in a municipality that did not own its own utility. His observations reinforced the role that government-owned utilities play in terms of capacity. "I went to a city that didn't have one. We started to talk about certain types of planning issues that related to sustainability and we started incorporating some of them into our base planning, but it was hard because generating the additional funds at the local level is always tough." 


\section{Local control}

Another factor that distinguishes the role of municipal utilities from investor-owned ones is the largely local nature of the former, according to interview subjects in three of the communities. Typical sentiment in these places was the comment from one official who said that, "you've got the flexibility and nimbleness and community ethic of a locally owned municipal utility...You don't have the bureaucracy or the shareholders ... We serve the community and the community was telling us that [energy conservation] was an important thing for them so that's how the value system went." The greater trust that residents tend to have in a local company is also an important aspect in the successful launch of sustainable energy programs according to the same interviewee. "You know most of the people and there's a certain level of trust that you are trying to help them... You're not a snake oil salesman. We live in this town. Our kids go to school here... I think all of those factors play into the level of trust and the success we've had."

Almost all interviewees mentioned that the close connection to customers makes education about energy conservation easier. One community, through its utility, promotes a "Go Dark" downtown on Earth Day when everyone turns out their lights. Another had a display in the village hall to demonstrate to people coming in to pay their utility bills the importance of changing to energy efficient light bulbs. Another community passes out welcome baskets to new residents; the baskets contain energy (and water) efficient fixtures and conservation information.

The local nature of the operation makes vetting new programs more thorough and tuned to local needs. At the local level, a publicly-owned power company has more control over responding to demand than a large investor-owned utility that often has customer environmental preferences spread across multiple states. One local official reported that in his community an advisory board meets to discuss new energy and conservation programs and challenges. In this 
committee, the proposals are refined before they are passed up to the city council. Reported another official, "we have direct control over the decision on how we will meet our customers' needs." For example, he said, the citizens did not want the municipality to partner on the construction of a new coal-fired plant, which might have produced power more cheaply than renewable alternatives. The city council responded to those wishes and pulled the plug on participation in the project.

Local control also allows for the quicker dissemination and evaluation of new conservation strategies. One official described his utility's practice of annually reviewing conservation programs, "so you can find out if there's success or failure pretty rapidly and [we can] expand the successful ones and wean ourselves off of the ones that are not as successful." Another official said that the access to electricity usage data, which is often not easy to obtain from investor-owned utilities, makes evaluation "easy since you own the utility. You can watch the meters turn." However, only three municipalities reported using the available electricity usage data to track program success.

\section{Limits of municipal utilities}

While recognizing the important role that municipal utilities may play in sustainability policymaking and implementation, the respondents described some limitations. One limitation mentioned by numerous people is the fact that energy conservation efforts cut into electricity sales. For many utilities with fixed capital and operating costs, potential losses of revenue make conservation counterintuitive. One manager said, "it's kind of a strange thing, if you think about it in terms of an enterprise. We are basically investing money so people don't buy as much of our product." Another official said that if his conservation programs had been as effective in the industrial sector as they have been in the residential, then the drop in electricity sales would have 
made operating the utility difficult. Two managers mentioned that they will likely have to increase electric rates in the future. The officials admitted that such increases burden low- and middle-income families as they often do not have the money to invest in reducing electricity use in their households even with subsidies. One leader espoused a more positive view of reduced energy sales. While admitting it is a challenge, he works to convince his elected officials that lowering customer bills is a net positive because the money saved by residents is spent in the community.

The lower cost of electricity sold by municipal utilities has also worked against sustainability efforts by some municipalities. In one rural community, a place in which many residents use electricity for heat, the mayor lamented that his constituents have become "spoiled, because they were used to [electricity] not costing that much. So they leave the windows open at night... they keep [the temperature] set at 75 degrees instead of 69 or 70." Another local official, who touts many sustainability policies in areas other than energy, admits that energy conservation has been stalled because of the low prices. And one city manager said that he has publicly advocated for raising prices in order to encourage conservation while admitting that the position has not been very popular.

\section{Conclusion - The externalities of public ownership}

The mixed methods approach employed in this paper has allowed me to examine two important aspects of local government sustainability policymaking - the role of capacity and

local control. Statistically, I have demonstrated that the presence of a municipally-owned utility correlates to the increased the ability of local governments to act in terms of sustainable energy policies across the community. The regression model indicated - and the interviews with local officials confirmed - that municipal utilities can bring technical and fiscal capacity to local 
governments. This increased capacity is one of the positive externalities of municipal ownership of power companies.

The interviews also illuminated the increased flexibility and potential for more effective action of locally-based sustainable energy efforts. At least in the minds of these local officials, a closer connection to customers makes their programs better targeted to local needs, more accepted by residents, and thereby more successful - a long standing theory of local government service delivery (Fischel, 2001; Ostrom, 2010b; Tiebout, 1956). However, the role of municipal utilities in providing capacity indicates a more multilevel approach is needed to these global commons issues across all municipalities (Homsy and Warner, 2015). The vast majority of local governments without access to this local capacity engine need fiscal and technical resources, which could be provided in the U.S. by the state and federal governments.

Clearly, having a municipal utility is not a prerequisite for policymaking. Many municipalities find a sustainable way forward without owning their own electric or natural gas utility. The policy implications of this paper do not necessarily point to advocacy of increased municipal ownership of power companies. The Boulder experience, in which investor-owned utilities fought vociferously to hold on to their territory - and nearly succeeded (Driskell, 2012), indicates that the number of transitions to government ownership will remain small. (Although a number of local governments in Europe are re-municipalizing their power systems (Hall et al., 2013; Haney and Pollitt, 2013).) Instead, the research indicates that local governments with a publicly-owned power company may have important advantages that it may not recognize or employ. Supporting this were the related comments by a number of the interview subjects, who noted that ownership of other utilities (e.g. drinking water, storm water) helped in similar ways with sustainability policymaking and implementation in those areas. 
Finally, the findings also show that the debate around government provision of services needs to recognize the potential positive externalities of public ownership. The decision to embrace private or public provision often focuses on cost or quality of services provided. The case of municipal utilities indicates that local institutions may have broader impacts that need to be factored into any decision whether to contract out or contract back in particular services.

\section{References}

American Public Power Association, 2014, “2014-2015 Public Power Annual Directory \& Statistical Report", Author, Washington, DC, http://www.publicpower.org/Programs/Landing.cfm?ItemNumber=38710\&navItemNum ber $=37577$

American Public Power Association, 2013, "Q \& A for Communities Considering the Public Option", Author, Washington, DC, http://www.publicpower.org/files/PDFs/Forming\%5FQA\%5F2013.pdf

Axinn W G, Pearce L D, 2006 Mixed Method Data Collection Strategies (Cambridge University Press, New York)

Bae J, Feiock R, 2013, "Forms of Government and Climate Change Policies in US Cities" Urban Studies 50(4) 776-788

Barboza, T, 2014, “L.A., Houston, Philadelphia mayors vow more action on climate change" Los Angeles Times, http://www.latimes.com/science/sciencenow/la-sci-sn-mayors-climateagenda-20140921-story.html

Berry, J M and Portney, K E, 2013, "Sustainability and Interest Group Participation in City Politics" Sustainability 5(5) 2077-2097 
Betsill, M, 2001, "Mitigating climate change in US cities: Opportunities and obstacles" Local Environment 6(4) 393-406

Betsill, M and Bulkeley, H, 2006, "Cities and the multilevel governance of global climate change" Global Governance 12(2) 141-159

Betsill, M and Bulkeley, H, 2004, “Transnational Networks and Global Environmental Governance: The Cities for Climate Protection Program” International Studies Quarterly 48(2) 471-493

Betz, M R, Partridge, M D, Kraybill, D S, and Lobao, L, 2012, "Why Do Localities Provide Economic Development Incentives? Geographic Competition, Political Constituencies, and Government Capacity" Growth and Change 43(3) 361-391

Burby, R J and May, P J, 1998, “Intergovernmental environmental planning: Addressing the commitment conundrum” Journal of Environmental Planning and Management 41(1) 95-110

Carter, R and Culp, S, 2010, "Planning for Climate Change in the West", Lincoln Institute of Land Policy, Cambridge, MA

Center for Climate and Energy Solutions, 2011, "U.S. States \& Regions", http://www.c2es.org/states-regions

Conroy, M M and Iqbal, A-A, 2009, “Adoption of sustainability initiatives in Indiana, Kentucky, and Ohio" Local Environment 14(2) 109-125

Council on Environnmental Quality, 2013, “State, Local, and Tribal Leaders Task Force On Climate Preparedness and Resilience" The White House, http://www.whitehouse.gov/administration/eop/ceq/initiatives/resilience/taskforce Creswell J W, Clark V L P, 2011 Designing and Conducting Mixed Methods Research Second Edition edition (SAGE Publications, Inc, Los Angeles) 
Driskell, D, 2012 August 24, “The Power to Decide: Boulder's Energy Future” an invited talk at the City and Regional Planning Colloquium Series, Cornell University, Ithaca, NY

Erickson, P and Tempest, K, 2014, "The contribution of urban-scale actions to ambitious climate targets" (Stockholm Environment Institute-US Center, Davis, CA)

Fiorino, D J, 2010, “Sustainability as a Conceptual Focus for Public Administration” Public Administration Review 70(Special issue) s78-s88

Fiorino, D J, 2006 The New Environmental Regulation (The MIT Press, Cambridge, MA)

Fischel, W A, 2001 The Homevoter Hypothesis (Harvard University Press, Cambridge, MA)

Fisher, D R, 2013, "Understanding the relationship between subnational and national climate change politics in the United States: toward a theory of boomerang federalism" Environment and Planning C: Government and Policy 31(5) 769 - 784

Flanigan, T and Hadley, S, 1994, “Analysis of Successful Demand-Side Management at Publicly Owned Utilities”, Oak Ridge National Laboratory, Oak Ridge, TN, http://web.ornl.gov/sci/ees/etsd/pes/pubs/3445603869133.pdf

Frug, G E and Barron, D J, 2008 City Bound: How States Stifle Urban Innovation (Cornell University Press, Ithaca, NY)

Granovetter M, McGuire P, 1998, “The making of an industry: electricity in the United States" Sociological Review 46 147-173

Hall D, Lobina E, Terhorst P, 2013, "Re-municipalisation in the early twenty-first century: water in France and energy in Germany" International Review of Applied Economics 27(2) $193-214$

Haney A B, Pollitt M G, 2013, "New models of public ownership in energy” International Review of Applied Economics 27(2) 174-192 
Hanna, K S, 2005, "Planning for Sustainability: Experiences in Two Contrasting Communities" Journal of the American Planning Association 71(1) 27-40

Harrison C, 2013, “The historical-geographical construction of power: electricity in Eastern North Carolina" Local Environment 18(4) 469-486

Hausman W J, Neufeld J L, 1990, “The Structure and Profitability of the Us Electric Utility Industry at the Turn of the Century" Business History 32(2) 225

Hausman W J, Neufeld J L, 2011, "How politics, economics, and institutions shaped electric utility regulation in the United States: 1879-2009” Business History 53(5) 723-746

Heiman M K, Solomon B D, 2004, "Power to the People: Electric Utility Restructuring and the Commitment to Renewable Energy" Annals of the Association of American Geographers 94(1) 94-116

Homsy, G C and Warner, M E, 2015, "Cities and Sustainability: Polycentric Action and Multilevel Governance" Urban Affairs Review 51(1) 46-73

Homsy, G C and Warner, M E, 2012, "Off the Beaten Path: Sustainability Activities in Small Towns and Rural Municipalities”, in Municipal Year Book 2012 (ICMA Press, Washington, DC), pp 53-61

Honadle, B W, 2001, “Theoretical and practical issues of local government capacity in an era of devolution” Journal of Regional Analysis and Policy 31(1) 77-90

Hyman, L S, 1997 America's Electric Utilities: Past, Present, and Future Sixth (Public Utilities Reports, Inc., Arlington, VA)

ICLEI, 2011, “Member List — ICLEI Local Governments for Sustainability USA”, http://www.icleiusa.org/about-iclei/members/member-list

ICMA, 2010, “2010 Local Government Sustainability Policies and Programs Survey”, Author, Washington, DC, http://icma.org/en/results/surveying/survey_research/survey_results 
ICMA, 2012, “2012 Alternative Service Delivery Survey Dataset”, Author, Washington, DC.

Jepson, E J, 2004, “The Adoption of Sustainable Development Policies and Techniques in U.S. Cities: How Wide, How Deep, and What Role for Planners?” Journal of Planning Education and Research 23(3) 229-241

Jochem, E and Madlener, R, 2003, “The forgotten benefits of climate change mitigation: Innovation, technological leapfrogging, employment, and sustainable development", in Workshop on the Benefits of Climate Policy: Improving Information for Policy Makers (Paris)

Kousky, C and Schneider, S H, 2003, “Global climate policy: will cities lead the way?" Climate Policy 3(4) 359-372

Krause, R M, 2012, “An Assessment of the Impact that Participation in Local Climate Networks Has on Cities' Implementation of Climate, Energy, and Transportation Policies" Review of Policy Research 29(5) 585-604

Krause, R M, 2011, “Policy innovation, intergovernmental relations, and the adoption of climate protection initiatives by U.S. cities" Journal of Urban Affairs 33(1) 45-60

Kwon, M, Jang, H S, and Feiock, R C, 2014, “Climate Protection and Energy Sustainability Policy in California Cities: What Have We Learned?” Journal of Urban Affairs Online First

Lubell, M, Feiock, R C, and Handy, S, 2009, “City Adoption of Environmentally Sustainable Policies in California's Central Valley" Journal of the American Planning Association 75(3) 293-308

Lutsey, N and Sperling, D, 2008, “America's bottom-up climate change mitigation policy” Energy Policy 36(2) 673-685 
MacKillop F, 2005, “The Los Angeles 'Oligarchy' and the Governance of Water and Power Networks" Flux 60(2) 23-34

May, P J, Burby, R J, Ericksen, N J, Handmer, J W, Dixon, J E, Michaels, S, and Smith, D I, 1996 Environmental Management and Governance: Intergovernmental approaches to hazards and sustainability (Routledge, London)

Millard-Ball, A, 2012, "The Limits to Planning: Causal Impacts of City Climate Action Plans" Journal of Planning Education and Research, http://jpe.sagepub.com/content/early/2012/07/31/0739456X12449742

Nelson, K L and Svara, J H, 2012, "Form of Government Still Matters Fostering Innovation in U.S. Municipal Governments" The American Review of Public Administration 42(3) $257-281$

Ostrom, E, 2010a, "Nested externalities and polycentric institutions: must we wait for global solutions to climate change before taking actions at other scales?" Economic Theory 49(2) 353-369

Ostrom, E, 2010b, "Polycentric systems for coping with collective action and global environmental change" Global Environmental Change 20(4) 550-557

Portney, K E and Berry, J M, 2010, "Participation and the Pursuit of Sustainability in U.S. Cities" Urban Affairs Review 46(1) 119-139

Rayner, S, 2010, "How to Eat an Elephant: A Bottom-up Approach to Climate Policy” Climate Policy 10(6) 615-621

Rudolph, R and Ridley, S, 1986 Power Struggle: The Hundred Year War Over Electricity (Harper \& Row Publishers, New York)

Saha, D, 2009, “Factors Influencing Local Government Sustainability Efforts” State and Local Government Review 41(1) 39-48. 
Schap, D, 1986 Municipal Ownership in the Electric Utility Industry: A Centennial View (Praeger Publishers, New York)

Sharp, E B, Daley, D M, and Lynch, M S, 2011, “Understanding Local Adoption and Implementation of Climate Change Mitigation Policy" Urban Affairs Review 47(3) 433457

Short, J R, 2012, “Metropolitan USA: Evidence from the 2010 Census" International Journal of Population Research 2012 1-6

Sippel, M and Jenssen, T, 2009, "What about local climate governance? A review of promise and problems", http://mpra.ub.uni-muenchen.de/20987/

Smeloff, E and Asmus, P, 1997 Reinventing Electric Utilities: Competition, Citizen Action, and Clean Power (Island Press, Washington, DC)

Svara, J H, 2011, "The Early Stage of Local Government Action to Promote Sustainability”, in The Municipal Year Book 2011 (ICMA Press, Washington, DC), pp 43-60

Tang, Z, 2009, "How are California local jurisdictions incorporating a strategic environmental assessment in local comprehensive land use plans?” Local Environment 14(4) 313-328

Taylor, M, 2000, "Communities in the Lead: Power, Organisational Capacity and Social Capital" Urban Studies 37(5-6) 1019-1035

Thompson, V A, 1965, “Bureaucracy and Innovation” Administrative Science Quarterly 10(1) 120

Tiebout, C M, 1956, “A Pure Theory of Local Expenditures” The Journal of Political Economy 64(5) 416-424

UAMPS, 2014, “Utah Associated Municipal Power Systems” Smart Energy, http://www.uamps.com/index.php/smart-energy

U.S. Census Bureau, “American Community Survey, 2005-2009”, Author, Washington, DC 
U.S. Census Bureau, “Census of Local Governments, 2002”, Author, Washington, DC

U.S. Census Bureau, “Decennial Census, 2010”, Author, Washington, DC

U.S. Conference of Mayors, 2008, “The Impact of Gas Prices, Economic Conditions, and Resource Constraints on Climate Protection Strategies in U.S. Cities”, Author, Washington, D.C., http://www.usmayors.org/climateprotection/documents/2008\%20CP\%20Survey.pdf

Wallis, J and Dollery, B, 2002, "Social Capital and Local Government Capacity" Australian Journal of Public Administration 61(3) 76-85

Wilson, E J, Plummer, J, Fischlein, M, and Smith, T M, 2008, “Implementing energy efficiency: Challenges and opportunities for rural electric co-operatives and small municipal utilities” Energy Policy 36(9) 3383-3397

Zahran, S, Grover, H, Brody, S D, and Vedlitz, A, 2008, "Risk, Stress, and Capacity Explaining Metropolitan Commitment to Climate Protection" Urban Affairs Review 43(4) 447-474 